\title{
ESTIMATION OF COPPER INTAKE IN MODERATE WINE CONSUMERS IN CROATIA
}

\author{
Blanka TARIBA, Zorana KLJAKOVIĆ-GAŠPIĆ, and Alica PIZENT \\ Institute for Medical Research and Occupational Health, Zagreb, Croatia \\ Received in May 2011 \\ CrossChecked in June 2011 \\ Accepted in July 2011
}

\begin{abstract}
To estimate $\mathrm{Cu}$ exposure level from wine consumption and to assess possible health risk for moderate wine consumers, wine samples were collected from different wine-growing areas of Croatia. Median concentrations were $180 \mu \mathrm{g} \mathrm{L}^{-1}$, range (76 to 292) $\mu \mathrm{g} \mathrm{L}^{-1}$, in commercial wines and $258 \mu \mathrm{g} \mathrm{L}-1$, range (115 to 7600$) \mu \mathrm{g} \mathrm{L}{ }^{-1}$, in homemade wines ( $\left.\mathrm{P}>0.05\right)$. Maximum permitted level of $1000 \mu \mathrm{g} \mathrm{L}^{-1}$ was exceeded in three homemade wines. However, daily intake of $\mathrm{Cu}$ from wine (in the range from $0.02 \mathrm{mg} \mathrm{d}^{-1}$ to $1.52 \mathrm{mg}$ $\mathrm{d}^{-1}$ ) estimated from $\mathrm{Cu}$ concentration in all wine samples is lower than the tolerable upper intake level of $5 \mathrm{mg} \mathrm{d}^{-1}$ proposed by the EU Scientific Committee on Food and does not present a risk to moderate wine consumers.
\end{abstract}

KEY WORDS: commercial wines, dietary intake, homemade wines, risk assessment

The chemical composition of wine is very complex and contributes to the quality of wine. Metals in wine also affect its organoleptic characteristics. Copper $(\mathrm{Cu})$, iron $(\mathrm{Fe})$, and manganese $(\mathrm{Mn})$ often form stable complexes with amino acids and polyphenols, which occur during wine maturation and storage. These complexes determine ageing characteristics, final aroma, taste, and even the colour of wine (1).

Concentration of metals in wine, including $\mathrm{Cu}$, can depend on the contribution from soil on which vines are grown and reach wine through grapes, pesticide treatment used in wine-growing, various steps of the production cycle, and wine processing equipment, conservation, and bottling $(1,2)$. The concentration of $\mathrm{Cu}$ in wine may be lower than in grapes due to a formation of insoluble $\mathrm{Cu}$ sulphides during fermentation, which sediment and are removed with yeasts and lees $(3,4)$.

Intensive and long-term use of Cu-based compounds can have long-term adverse effects on the environment through toxicity to aquatic and soil organisms and can even affect human health. Although $\mathrm{Cu}$ is an essential metal for normal activity of many important enzymes, its excessive intake could result in its accumulation and harmful health effects. Symptoms of Cu poisoning include nausea, vomiting, and abdominal and muscle pain, as well as problems with coordination or movement (5). Since $\mathrm{Cu}$ deficiency and $\mathrm{Cu}$ excess produce adverse effects on organisms, it is important to monitor $\mathrm{Cu}$ level in wine, especially in countries with a long wine-producing and wine-consuming tradition such as Croatia. According to the International Organization of Vine and Wine (IOVW) (6), and Croatian legislation (7), the maximum permissible concentration of $\mathrm{Cu}$ in wine is $1000 \mu \mathrm{g} \mathrm{L} \mathrm{L}^{-1}$.

The aim of this study was to estimate the contribution of wine to dietary $\mathrm{Cu}$ intake and possible health risk for moderate wine consumers. Consumption data used in the assessment are based on national average consumption rates and the estimates have been derived for the general population from the analysed wine samples and available peer reviewed literature. 
Data were compared with Maximum Permissible Level and Tolerable Upper Intake Level for $\mathrm{Cu}$.

\section{MATERIALS AND METHODS}

\section{Sampling and analysis}

Ten commercial and fifteen non-commercial, homemade wines were obtained from 13 winemakers from six Croatian wine-growing areas (Dalmatia, Hrvatsko Primorje, Istria, Prigorje, Zagorje and Slavonia). All samples were packed in glass bottles and stored at $4{ }^{\circ} \mathrm{C}$. All reagents were of analytical grade. Working standard solutions were prepared from a $1000 \mathrm{mg} \mathrm{L}^{-1} \mathrm{Cu}$ standard solution (Merck, Darmstadt, Germany). First, $\mathrm{Cu}$ was analysed by flame atomic absorption spectrometry to screen for possible high concentrations, and then, for more accurate determination, by graphite furnace atomic absorption spectrometry (Perkin-Elmer 5100 spectrometer; Perkin-Elmer, Norwalk, CT, USA) with a Zeeman background correction (8). All measurements were performed in two independent replicates. When necessary, wine samples were diluted with Mili-Q water. As matrix modifier, $5 \mu \mathrm{g}$ of $\mathrm{PdNO}_{3}$ plus $3 \mu \mathrm{g}$ of $\mathrm{Mg}\left(\mathrm{NO}_{3}\right)_{2}$ × $6 \mathrm{H}_{2} \mathrm{O}$ (both Merck, Darmstadt, Germany) was used. Accuracy was evaluated by standard additions to determine recovery of the spiked sample. Spike recovery was tested with one red and one white commercial Croatian wine, randomly selected between the collected wine samples, because no certified reference material was available. Wine samples were spiked with five concentration levels of $\mathrm{Cu}$, none exceeding $80 \mu \mathrm{g} \mathrm{L}^{-1}$ for either red or white wine samples. The addition of appropriate volume of standard solution of $\mathrm{Cu}$ to commercially available Croatian wines resulted in an average recovery of $(95 \pm 15) \%$ for red, and $(100 \pm 11) \%$ for white wine. Measurements of ten different replicates of one red and one white wine sample (measured in triplicate) gave relative standard deviations of $1.11 \%$ and $2.58 \%$, respectively, indicating high within-run precision. The detection limit of $4 \mu \mathrm{g} \mathrm{L}^{-1}$ was calculated as three times the standard deviation of 25 consecutive measurements of the blank sample $(3 \sigma)$. The quantification limit of $13 \mu \mathrm{g} \mathrm{L}^{-1}$ was calculated as ten times the standard deviations of 25 consecutive measurements of the blank sample $(10 \sigma)$.

\section{Statistics}

Since the data were not normally distributed, the significance of difference in $\mathrm{Cu}$ concentrations between commercial and homemade wines, and between subgroups of white and red wines was calculated using the Mann-Whitney U-test. The test was applied on the total number of samples. Results were considered significant at the $5 \%$ level $(\mathrm{P}<0.05)$

\section{RESULTS AND DISCUSSION}

Median $\mathrm{Cu}$ values were $180 \mu \mathrm{g} \mathrm{L} \mathrm{L}^{-1}$ (range from $76 \mu \mathrm{g} \mathrm{L}^{-1}$ to $292 \mu \mathrm{g} \mathrm{L}^{-1}$ ) in commercial wines and $258 \mu \mathrm{g} \mathrm{L}^{-1}$ (range from $115 \mu \mathrm{g} \mathrm{L}^{-1}$ to $7600 \mu \mathrm{g} \mathrm{L}^{-1}$ ) in non-commercial, homemade wines. In all commercial wines and in 10 of 13 homemade wines $\mathrm{Cu}$ ranged between $76 \mu \mathrm{g} \mathrm{L}^{-1}$ and $567 \mu \mathrm{g} \mathrm{L}{ }^{-1}$, which is far below the upper permissible limit of $1000 \mu \mathrm{g} \mathrm{L}^{-1}(6,7)$. Concentrations above the permitted level were found in three homemade wines, possibly because of too intensive use of $\mathrm{Cu}$-fungicides, too short period between the last application and harvest, or noncompliance to technological norms. No statistically significant difference in $\mathrm{Cu}$ levels was found between commercial and homemade wines or between the subgroups of red and white wines.

Our $\mathrm{Cu}$ findings for commercial wines are comparable with most reports from other European countries (Table 1). Lower $\mathrm{Cu}$ was reported for wines from Argentina (9), and higher $\mathrm{Cu}$ for wines from Australia (10), Brazil (11), Czech Republic (12), and Serbia $(13,14)$.

Before this study, several other authors published data on $\mathrm{Cu}$ concentration in Croatian wines (Table 2). Only Banović et al. (15), who measured concentration of $\mathrm{Cu}, \mathrm{Fe}, \mathrm{Zn}$, and $\mathrm{Pb}$ in one Croatian autochthonous sort of red wine produced by various producers over three consecutive seasons, reported $\mathrm{Cu}$ level higher than $1000 \mu \mathrm{g} \mathrm{L}^{-1}$ in one wine sample per season. Our results confirm low levels of $\mathrm{Cu}$ in Croatian wines.

However, cases of excessive $\mathrm{Cu}$ levels suggest that the wine producers should be more aware of possible sources of metals in their wines. Environmental dispersion of fertilizers and pesticides used in viticulture, or contact with copper or bronze materials in winemaking can easily result in elevated concentrations of $\mathrm{Cu}$ in wine. Therefore, regular control of metal concentrations in wine during all steps 
Table 1 Concentrations of copper in commercial wine samples from various countries

\begin{tabular}{|c|c|c|c|c|}
\hline \multirow{2}{*}{ Country } & \multirow{2}{*}{$\begin{array}{c}\text { Number of } \\
\text { samples }\end{array}$} & \multicolumn{2}{|c|}{$\gamma(\mathbf{C u}) / \mu \mathrm{g} \mathrm{L}^{-1}$} & \multirow{2}{*}{ Reference } \\
\hline & & Range & Mean value & \\
\hline Argentina & - & 23 to 28 & - & (9) \\
\hline Portugal & 7 & 50 to 220 & $100^{\mathrm{b}}$ & (26) \\
\hline Macedonia & 4 & 210 to 250 & - & (27) \\
\hline Bulgaria & 2 & 190 to 250 & - & $(27)$ \\
\hline Spain & 10 & 32 to 330 & 110 & $(28)$ \\
\hline Slovenia & 10 & 60 to 300 & 120 & $(4)$ \\
\hline Hungary & 35 & 20 to 642 & $150 \pm 1.34$ & (29) \\
\hline Spain & 6 & 28.4 to 490 & $150^{\mathrm{b}}$ & $(30)$ \\
\hline Italy & 16 & 74.7 to 500 & $152^{\mathrm{b}}$ & $(31)$ \\
\hline Croatia & 25 & 76 to 292 & 180 & this study \\
\hline Brazil & 29 & 69 to 1011 & 197 & (11) \\
\hline Spain (Tenerife) & 125 & 30 to 1190 & 240 & $(32)$ \\
\hline Germany & 150 & 50 to 394 & 250 & (33) \\
\hline Italy & 4 & 116.7 to 462 & $261^{\mathrm{b}}$ & $(34)$ \\
\hline Serbia & 5 & 100 to 460 & - & $(14)$ \\
\hline Turkey & 2 & 160 to 460 & - & $(27)$ \\
\hline Greece & 45 & 200 to 600 & - & (35) \\
\hline Uruguay & 47 & 34 to 650 & - & $(36)$ \\
\hline Australia & 24 & $\mathrm{ND}^{\mathrm{a}}$ to 1800 & $330 \pm 0.41$ & $(10)$ \\
\hline Czech Republic & 31 & 12.8 to 6827 & 448 & $(12)$ \\
\hline Italy & 11 & 140 to 930 & $460^{\mathrm{b}}$ & $(37)$ \\
\hline Serbia & 8 & 90 to 2300 & 580 & (13) \\
\hline Jordan & 60 & 27 to 2600 & - & (38) \\
\hline
\end{tabular}

${ }^{a}$ Not detected

${ }^{b}$ Median value

of wine production and "corrective treatments suggested by modern oenological techniques" (3) prior to packaging and consumption can prevent excessive metal intake.

$\mathrm{Cu}$ is mainly absorbed through the gastrointestinal tract. From $20 \%$ to $60 \%$ of dietary $\mathrm{Cu}$ is absorbed, with the rest being excreted in faeces. When $\mathrm{Cu}$ homoeostatic control is defective and/or $\mathrm{Cu}$ intake is excessive, $\mathrm{Cu}$ toxicity may occur. Ingestion of excess $\mathrm{Cu}$ is infrequent in humans and is usually a consequence of contamination of beverages (including drinking water) (16). Acute adverse effects of elevated $\mathrm{Cu}$ intake are those on the gastrointestinal tract, such as nausea, abdominal pain, vomiting, and diarrhoea. Chronic overexposure to $\mathrm{Cu}$ can damage the liver and kidneys. Liver damage has been reported at extremely high $\mathrm{Cu}$ intake of $>30 \mathrm{mg} \mathrm{d}^{-1}$ (5). Recently, several studies have investigated the hypothesis that excessive amounts of $\mathrm{Cu}$ in some regions of the brain may trigger and/or speed up a number of neurological disorders including Alzheimer's disease (AD), familial amyotrophic lateral sclerosis (ALS), and CreutzfeldtJakob disease (CJD) (17-19). However, the role of $\mathrm{Cu}$ in $\mathrm{AD}, \mathrm{ALS}$, and CJD is still unclear, and future studies in this area are needed. According to the National Academy of Sciences (20), the tolerable upper intake level (UL) for adults is $10 \mathrm{mg}$ of $\mathrm{Cu}$ per day, whereas the EU Scientific Committee on Food (21) has set it to $5 \mathrm{mg} \mathrm{d}^{-1}$. The Recommended Dietary Allowance (RDA) for adult men and women is $0.9 \mathrm{mg} \mathrm{d}^{-1}$.

Based on mean or median and peak $\mathrm{Cu}$ concentrations in wine samples from our and other Croatian studies and on reported alcohol annual consumption, we calculated the $\mathrm{Cu}$ daily intake by moderate Croatian wine consumers $(0.2 \mathrm{~L}$ per day) (Table 2). According to the EU legislation (Directive 793/93/EC), "typical" exposure is defined by median (22) and acute exposure by peak $\mathrm{Cu}$ concentration 
Table 2 Copper concentrations in Croatian wine across several studies and our assessment of exposure

\begin{tabular}{|c|c|c|c|c|c|c|c|}
\hline \multirow{2}{*}{ Reference } & \multirow{2}{*}{$\begin{array}{l}\text { Number } \\
\text { of samples }\end{array}$} & \multicolumn{3}{|c|}{$\gamma(\mathrm{Cu}) / \mu \mathrm{g} \mathrm{L}^{-1}$} & \multirow{2}{*}{$\begin{array}{c}\text { Wine } \\
\text { consumption / } \\
\text { L d }^{-1}\end{array}$} & \multirow{2}{*}{$\begin{array}{c}\text { "Typical" } \\
\text { exposure / } \\
\text { mg d }^{-1} \\
\end{array}$} & \multirow{2}{*}{$\begin{array}{l}\text { Acute exposure / } \\
\qquad \text { mg d }^{-1}\end{array}$} \\
\hline & & Min & Max & Mean & & & \\
\hline (39) & - & - & - & 6 & 0.2 & $<0.01$ & - \\
\hline (40) & 78 & 10 & 413 & 156 & 0.2 & 0.03 & 0.03 \\
\hline (41) & 10 & $32.3^{\mathrm{a}}$ & $539^{a}$ & - & 0.2 & - & 0.11 \\
\hline (42) & 26 & 48.5 & 726 & - & 0.2 & - & 0.14 \\
\hline This study & 25 & 76 & $7600^{b}$ & $189^{c}$ & 0.2 & 0.04 & 1.52 \\
\hline (43) & 20 & 90 & 930 & 410 & 0.2 & 0.08 & 0.06 \\
\hline$(15)$ & 30 & 212 & 1230 & 570 & 0.2 & 0.11 & 0.25 \\
\hline
\end{tabular}

"Typical" exposure is defined by median or mean values. Acute exposure is defined by the highest concentration.

${ }^{a}$ Range of mean concentrations

${ }^{b}$ The highest value of $\mathrm{Cu}$ measured in homemade wine sample

${ }^{c}$ Median value

(23). Average annual consumption of pure alcohol equivalent in Croatia in 2009 was $9.2 \mathrm{~L}$ per person (24). For comparison, average annual alcohol consumption in the EU in 2005 was $9.24 \mathrm{~L}$ of pure alcohol per person (25). Given an alcohol content of $12 \%$ for wine, this corresponds to an annual wine consumption of approximately $77 \mathrm{~L}$ or $0.2 \mathrm{~L} \mathrm{~d}^{-1}$. Given the median and peak $\mathrm{Cu}$ concentrations measured in commercial wine samples from this study and consumption of $0.2 \mathrm{~L}$ wine per day, "typical" and acute $\mathrm{Cu}$ exposure from wine would be $0.04 \mathrm{mg} \mathrm{d}^{-1}$ and $0.06 \mathrm{mg} \mathrm{d}^{-1}$, respectively. Taking into account the highest $\mathrm{Cu}$ level measured in a homemade wine sample, acute $\mathrm{Cu}$ exposure would be $1.52 \mathrm{mg} \mathrm{d}^{-1}$. These results show that even elevated $\mathrm{Cu}$ concentrations found in the three homemade wine samples do not pose a risk to moderate consumers of wine. However, consumption of wine with elevated $\mathrm{Cu}$ concentrations can pose a risk to people who drink over $0.5 \mathrm{~L} \mathrm{~d}^{-1}$ of such wine, as they ingest more $\mathrm{Cu}$ than the tolerable upper intake level.

Our findings support the need to monitor and control commercial wine $\mathrm{Cu}$ levels. The issue at hand however is broad-based education of home winemakers and control of $\mathrm{Cu}$ levels in their wines, as they seem to pose a greater risk of exposure.

\section{Acknowledgements}

This study was supported by the Ministry of Science, Education and Sports of the Republic of Croatia (grant No. 022-0222411-2408).

\section{REFERENCES}

1. Pohl P. What do metals tell us about wine? Trends Anal Chem 2007;26:941-9.

2. Stafilov T, Karadjova I. Atomic absorption spectrometry in wine analysis. A Review. Maced J Chem Chem Eng 2009;28:17-31.

3. Volpe MG, La Cara F, Volpe F, De Mattia A, Serino V, Petitto F, Zavalloni C, Limone F, Pellecchia R, De Prisco PP, Di Stasio M. Heavy metal uptake in the enological food chain. Food Chem 2009;117:553-60.

4. Kristl J, Veber M, Slekovec M. The contents of $\mathrm{Cu}, \mathrm{Mn}, \mathrm{Zn}$, $\mathrm{Cd}, \mathrm{Cr}$ and $\mathrm{Pb}$ at different stages of the winemaking process. Acta Chim Slov 2003;50:123-36.

5. World health Organization (WHO). Copper. Environmental Health Criteria 200 [displayed 16 April 2011]. Available at http://www.inchem.org/documents/ehc/ehc/ehc200.htm.

6. International Organisation of Vine and Wine (IOVW). International code of oenological practices 2006 [displayed 16 July 2010]. Available at http://news.reseau-concept.net/ $\mathrm{i} \mathrm{mages} / \mathrm{oi} \mathrm{v}$ u k/C $1 \mathrm{i}$ e $\mathrm{nt} / \mathrm{P} \mathrm{NO} 02 \mathrm{~A}$ CODE \%20Ed \%202006 \%20EN.pdf.

7. Pravilnik o toksinima, metalima, metaloidima te drugim štetnim tvarima koje se mogu nalaziti u hrani [Legislation on toxins, metals, metaloids and other harmful supstances that could be contained in food, in Croatian]. Narodne novine $16 / 2005$.

8. Catarino S, Pimentel I, Curvelo-Garcia AS. Determination of copper in wine by ETAAS using conventional and fast thermal programs: Validation of analytical method. At Spectrosc 2005;25:73-8.

9. Lara R, Cerutti S, Salonia JA, Olsina RA, Martinez LD. Trace element determination of Argentine wines using ETAAS and USN-ICP-OES. Food Chem Toxicol 2005;43:293-7.

10. Sauvage L, Frank D, Stearne J, Millikan MB. Trace metal studies of selected white wines: an alternative approach. Anal Chim Acta 2002;458:223-30. 
11. Mirlean M, Roisenberg A, Chies JO. Copper-based fungicide contamination and metal distribution in Brazilian grape products. Bull Environ Contam Toxicol 2005;75:968-74.

12. Kment P, Mihaljevič M, Ettler V, Šebek O, Strnad L, Rohlová L. Differentiation of Czech wines using multielement composition - A comparison with vineyard soil. Food Chem 2005;91:157-65.

13. Ražić $\mathrm{S}$, Čokeša $Đ$, Sremac $\mathrm{S}$. Multivariate data visualization methods based on elemental analysis of wines by atomic absorption spectrometry. J Serb Chem Soc 2007;72:148792.

14. Suturović ZJ, Marjanović NJ. Determination of zinc, cadmium, lead and copper in wines by potentiometric stripping analysis. Nahrung 1998;42:36-8.

15. Banović M, Kirin J, Curko N, Kovačević Ganić K. Influence of vintage on $\mathrm{Cu}, \mathrm{Fe}, \mathrm{Zn}$ and $\mathrm{Pb}$ content in some Croatian red wines. Czech J Food Sci 2009;29(Special issue):401-3.

16. Pizarro F, Olivares M, Uauy R, Contreras P, Rebelo A, Gidi V. Acute gastrointestinal effects of graded levels of copper in drinking water. Environ Health Perspect 1999;107:11721.

17. Atwood CS, Huang X, Moir RD, Tanzi RE, Bush AI. Role of free radicals and metal ions in the pathogenesis of Alzheimer's disease. Met Ions Biol Syst 1999;36:309-64.

18. Atwood CS, Scarpa RC, Huang X, Moir RD, Jones WD, Fairlie DP, Tanzi RE, Bush AI. Characterization of copper interactions with Alzheimer amyloid beta peptides: identification of an attomolar-affinity copper binding site on amyloid beta1-42. J Neurochem 2000;75:1219-33.

19. Opazo C, Huang X, Cherny RA, Moir RD, Roher AE, White AR, Cappai R, Masters CL, Tanzi RE, Inestrosa NC, Bush AI. Metalloenzyme-like activity of Alzheimer's disease betaamyloid. $\mathrm{Cu}$-dependent catalytic conversion of dopamine, cholesterol, and biological reducing agents to neurotoxic $\mathrm{H}_{2} \mathrm{O}_{2}$. J Biol Chem 2002;277:40302-8.

20. National Academy of Sciences, Institute of Medicine, Food and Nutrition Board. Dietary Reference Intakes for vitamin $\mathrm{A}$, vitamin $\mathrm{K}$, arsenic, boron, chromium, copper, iodine, iron, manganese, molybdenum, nickel, silicon, vanadium, and zinc. Washington (DC): National Academy Press; 2000.

21. Scientific Committee on Food, European Food Safety Authority. Tolerable Upper Intake Levels for Vitamins and Minerals, 2006 [displayed 6 April 2011]. Available at http:// www.efsa.europa.eu/en/ndatopics/docs/ndatolerableuil.pdf.

22. Sadhra SS, Wheatley AD, Cross HJ. Dietary exposure to copper in the European Union and its assessment for EU regulatory risk assessment. Sci Total Environ 2007;374:22334.

23. Lagos GE, Maggi LC, Peters D, Reveco F. Model for estimation of human exposure to copper in drinking water Sci Total Environ 1999;239:49-70.

24. Croatian Bureau of Statistics. Results of Households Budget Survey, 2009 [displayed 16 April 2011]. Available at http:// www.dzs.hr/Hrv_Eng/publication/2010/SI-1426.pdf.

25. World health Organization (WHO). European Status Report on Alcohol and Health 2010 [displayed 6 April 2011] Available at http://www.euro.who.int/_data/assets/pdf file/0004/128065/e94533.pdf.

26. Azenha MAGO, Vasconcelos MTSD. Assessment of the Pb and $\mathrm{Cu}$ in vitro availability in wines by means of speciation procedures. Food Chem Toxicol 2000;38:899-912.
27. Karadjova I, Izgi I, Gucer S. Fractionation and speciation of $\mathrm{Cu}, \mathrm{Zn}$ and $\mathrm{Fe}$ in wine samples by atomic absorption spectrometry. Spectrochim Acta Part B 2002;57:581-90.

28. Llobat-Estellés M, Mauri-Aucejo AR, Marin-Saez R. Detection of bias errors in ETAAS. Determination of copper in beer and wine samples. Talanta 2006;68:1640-7.

29. Ajtony Z, Szoboszlai N, Suskó EK, Mezei P, György K, Bencs L. Direct sample introduction of wines in graphite furnace atomic absorption spectrometry for the simultaneous determination of arsenic, cadmium, copper and lead content. Talanta 2008;76:627-34.

30. Pérez-Jordán MY, Soldevila J, Salvador A, Pastor A, de la Guardia M. Inductively coupled plasma mass spectrometry analysis of wines. J Anal Atom Spectrom 1998;13:33-9.

31. La Torre GL, La Pera L, Rando R, Lo Turco V, Di Bella G, Saitta M, Dugo G. Classification of Marsala wines according to their polyphenol, carbohydrate and heavy metal levels using canonical discriminant analysis. Food Chem 2008;110:729-34.

32. Conde JE, Estévez D, Rodríguez-Bencomo JJ, García Montelongo FJ, Pérez-Trujillo JP. Characterization of bottled wines from the Tenerife Island (Spain) by their metal ion concentration. Ital J Food Sci 2002;14:375-87.

33. Ostapczuk P, Eschnauer HR, Scollary GR. Determination of cadmium, lead and copper in wine by potentiometric stripping analysis. Fresenius J Anal Chem 1997;358:723-7.

34. Provenzano MR, El Bilali H, Simeone V, Baser N, Mondelli D, Cesari G. Copper contents in grapes and wines from a Mediterranean organic vineyard. Food Chem 2010;122:133843.

35. Galani-Nikolakaki S, Kallithrakas-Kontos N, Katsanos AA. Trace element analysis of Cretan wines and wine products. Sci Total Environ 2002;285:155-63.

36. Rivero Huguet ME. Monitoring of $\mathrm{Cd}, \mathrm{Cr}, \mathrm{Cu}, \mathrm{Fe}, \mathrm{Mn}, \mathrm{Pb}$ and $\mathrm{Zn}$ in fine Uruguayan wines by atomic absorption spectroscopy. At Spectroscop 2004;25:177-84.

37. Tamasi G, Pagni D, Carapelli C, Justice NB, Cini R. Investigation on possible relationships between the content of sulfate and selected metals in Chianti wines. J Food Compos Anal 2010;23:333-9.

38. Al Nasir FM, Jiries AG, Bataserh MI, Beese F. Pesticides and trace metal residue in grape and home made wine in Jordan. Environ Monit Assess 2001;66:253-63.

39. Oreščanin V, Katunar A, Kutle A, Valković V. Heavy metals in soil, grape, and wine. J Trace Microprobe Tech 2003;21:171-80.

40. Šeruga M, Nemet I, Laslavić B. Heavy metals content of some Croatian wines. Deut Lebensm-Rundsch 2008; 104:4655.

41. Vinković Vrček I, Bojić M, Žuntar I, Mendaš G, Medić-Šarić M. Phenol content, antioxidant activity and metal composition of Croatian wines deriving from organically and conventionally grown grapes. Food Chem 2011;124:354-61.

42. Fiket Ž, Mikec N, Kniewald G. Arsenic and other trace elements in wines of eastern Croatia. Food Chem 2011;126:941-7.

43. Šebečić B, Pavišić-Strache D, Vedrina-Dragojević I. Trace elements in wine from Croatia. Deut Lebensm-Rundsch 1998;94:341-4. 


\section{Sažetak}

\section{PROCJENA UNOSA BAKRA UMJERENOM KONZUMACIJOM VINA}

Kako bi se procijenila razina izloženosti bakru prilikom konzumacije vina te utvrdili mogući zdravstveni rizici za umjerene potrošače vina, skupljeni su i ispitani uzorci vina iz različitih vinogradarskih područja Hrvatske. Koncentracije Cu bile su u rasponu od $76 \mu \mathrm{g} \mathrm{L}^{-1}$ do $292 \mu \mathrm{g} \mathrm{L}^{-1}$ (medijan $180 \mu \mathrm{g} \mathrm{L}^{-1}$ ) u komercijalnim vinima te od $115 \mu \mathrm{g} \mathrm{L}-1$ do $7.600 \mu \mathrm{g} \mathrm{L}^{-1}$ (medijan $258 \mu \mathrm{g} \mathrm{L}^{-1}$ ) u vinima domaće proizvodnje $(\mathrm{P}>0,05)$. $\mathrm{U}$ tri ispitana vina domaće proizvodnje koncentracija $\mathrm{Cu}$ bila je iznad najviše dopuštene od $1000 \mu \mathrm{g} \mathrm{L}^{-1}$. Međutim, izračunani dnevni unos $\mathrm{Cu}$ u slučaju konzumacije ispitanih vina (u rasponu od

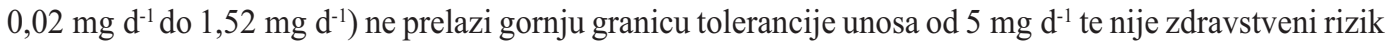
umjerenim potrošačima vina.

KLJUČNE RIJEČI: dnevni unos, Hrvatska, procjena rizika, vino

\section{CORRESPONDING AUTHOR:}

Blanka Tariba

Analytical Toxicology and Mineral Metabolism Unit Institute for Medical Research and Occupational Health

Ksaverska cesta 2, 10001 Zagreb, Croatia

E-mail: btariba@imi.hr 